\title{
Research and Practice of Engineering Training Teaching Methods based on Hierarchical Modularity
}

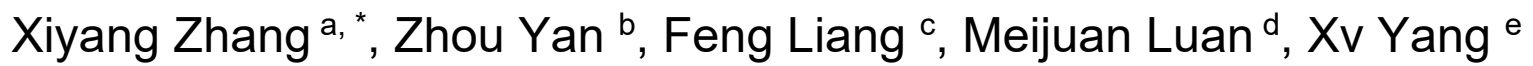 \\ School of Engineering Training Center, Shenyang Aerospace University, Shenyang, 110136, \\ China \\ a, * 420484832@qq.com, b sdyanzhou16888@163.com, c 408856378@qq.com, \\ d88454425@qq.com, e312428849@qq.com
}

\begin{abstract}
Engineering training is an important course to cultivate college students' practical ability, engineering consciousness and innovative spirit, and it is a necessary means to realize the goal of cultivating innovative talents. The teaching of CAD/CAM practical training has been constantly updated, keep pace with the time, use interesting modeling cases as a teaching guide. The practical teaching mode with aviation parts as the main teaching content, let college students get substantial exercise in engineering training.
\end{abstract}

Keywords: Prediction Practical Teaching; Case Guidance; Modularization; Reform in Education.

\section{Research Status at Home and Abroad}

CAD/CAM technology has evolved over the decades, has gone through the mainframe, small machine, workstation, microcomputer era. Now workstations and microcomputer platform $\mathrm{CAD} / \mathrm{CAM}$ software has dominated, and a number of excellent commercial software has emerged. After years of promotion, CAD technology has been widely used in machinery, electronics, aerospace and other industries, CAD Technology has played a role in improving the design efficiency of enterprises, optimizing design solutions, reducing the labor intensity of technical personnel, shortening the design cycle.

\section{Project Research Content}

\subsection{Specific Reform Contents}

(1) Give full play to the characteristics of aviation, engineering and training characteristics, to aviation parts as the operating standards, Design and simulation processing with UG software, comprehensive exercise of students' CAD/CAM ability, and thus achieve the practical effect of students' engineering training. The engineering training center is responsible for cultivating students' engineering quality and innovation ability [1]. The focus of the course was to transform from the UG modeling module to the process simulation module, Pay attention to the practical ability of students, close to the enterprise model teaching.

(2) The first half of the course is in the form of participatory teaching. The role change between teachers and students is student-led, students complete the modeling tasks at the beginning of the hands-on course on their own and in the course of operation with the students to share specific practices. Students who listen to the class should find out and ask questions. Through contact with the actual engineering, and then improve students' comprehensive engineering ability and innovative thinking [2]. in order to stimulate all students to listen to the focus of the class, improve the ability to analyze the problem. Guide the teacher in the student's explanation, In-depth understanding of the familiarity of students and be able to find problems in a timely manner. In turn, corrective and guidance is given in the second half of the course. 


\subsection{Teaching Method}

(1) Curriculum construction. The participatory teaching model is adopted, deep integration of "teaching and learning, listening and doing". Take advantage of hands-on teaching in the classroom, give full play to the atmosphere of free and open teaching and learning. With the rapid development of information technology, engineering practice uses information technology to carry out teaching management reform to become a trend and will certainly give engineering technology diversification and personalized talent training model to provide new possibilities and paradigms [3]. Improve students' learning initiative and the comprehensiveness of thinking about problems.

(2) Student training. The traditional engineering practical training teaching mainly uses the field explanation of the practical training site and carries on the practical demonstration, Students' learning resources mainly come from practical training materials and theoretical course knowledge. In the course of engineering training and learning, students of all majors in the school's mechanical class develop and innovate their ability with the consciousness of "teaching and learning, listening and doing", will greatly improve the practical interest, improve the level of practical operation. Can fully meet the requirements of modern enterprises for college students' practical ability, for the future job search and development to lay a solid foundation.

Table 1. Project evaluation process

\begin{tabular}{|c|c|c|}
\hline stage & content & Result \\
\hline \multirow{3}{*}{ Pre class inspection } & $\begin{array}{c}\text { Publish CAD/CAM Software training } \\
\text { requirements }\end{array}$ & \multirow{3}{*}{$\begin{array}{l}\text { Test the CAD/CAM foundation for } \\
\text { mechanical students }\end{array}$} \\
\hline & $\begin{array}{c}\text { Students complete aerial parts modeling on } \\
\text { their own }\end{array}$ & \\
\hline & The teacher's inspection found the problem & \\
\hline \multirow[t]{2}{*}{ involvement } & $\begin{array}{l}\text { Student representatives perform role } \\
\text { transitions and teach the process }\end{array}$ & \multirow{2}{*}{$\begin{array}{l}\text { Discover problem stages Role } \\
\text { change, participatory teaching }\end{array}$} \\
\hline & Students observe and ask questions & \\
\hline $\begin{array}{l}\text { Teacher resolve the } \\
\text { question }\end{array}$ & $\begin{array}{l}\text { On the basis of finding problems, understand } \\
\text { the basics of students' operation and solve } \\
\text { common problems }\end{array}$ & $\begin{array}{l}\text { Practical observation of students' } \\
\text { learning basis Intuitive discovery of } \\
\text { common problems }\end{array}$ \\
\hline remarks & \multicolumn{2}{|c|}{$\begin{array}{l}\text { Through participatory teaching, students' learning foundation is found, and students' } \\
\text { common problems are quickly found and solved. }\end{array}$} \\
\hline
\end{tabular}

(3) Teacher literacy. Through the research of the participatory practical teaching mode of hierarchy and modularity, the practical teaching reform and research work of "teaching and learning, listening and doing" ability are cultivated, The teaching staff has made a breakthrough in the practical teaching concept, theory and practice research of engineering training, and built a solid foundation, broad professional knowledge, strong hands-on ability and high comprehensive quality engineering training to guide the teachers, and promote the transformation of Shenyang education [4].

(4) Characteristics and innovation. This project breaks the traditional model of teachers speaking and students listening, and adopts the participatory practical teaching model. After the students complete the teaching content stipulated in the syllabus, according to the students' ability and choice, the teaching is arranged in different levels and diversity to achieve the goal of multi-level engineering training and training [5]. Teachers and students to change roles, student-led, so that students as teachers to complete the role of practical course start modeling tasks, and in the course of operation with students to share specific practices. At the same time, students who listen to the class should find and ask questions to motivate all students to listen to the focus of the class, improve the ability to analyze the problem.

The instructor can observe the whole operation process of the students in the student's explanation, deeply understand the students' familiarity, and be able to find the problem in time, and then give correction and guidance in the second half of the course. 


\section{An Important Point of View of Research Practice}

\subsection{Highlights the Aviation Features}

Using aviation parts as the main research teaching content, close to the characteristics of aviation, closely linked with the theoretical course, the best results of theoretical contact with reality.

\subsection{Improve the Enthusiasm for Learning}

In the course of teaching and teaching content, students' interest and enthusiasm in the study of engineering training projects is not high, and the teacher's enthusiasm for teaching is gradually weakening. Only by stimulating students' inner enthusiasm can we improve the efficiency of learning and achieve good learning and training results[6]. After a period of practice, effectively solve this phenomenon.

\subsection{The Effect of Fun Guided Teaching is Remarkable}

Teaching cases keep pace with the times, integrate the interesting modeling cases as a guide, close to the hearts of students in the new era, thus effectively enhancing students' interest in engineering training software practical training courses, and promoting students' practical hands-on ability training and training.

\section{Conclusion}

The implementation of this project, Let the engineering training practice course play a greater role in the participatory teaching mode.

In addition, in the course of teaching and teaching content, students' interest and enthusiasm in engineering training projects is not high, and the teacher's enthusiasm for teaching is gradually waning. Pay attention to the accumulation of experience, tap their own characteristics, in the inheritance and development of traditional teaching models on the basis of different majors, different levels of students to carry out hierarchical, modular teaching reform.

\section{Acknowledgments}

This work was financially supported by 2021 Shenyang Aerospace University Undergraduate Teaching Reform Research Project. Project fund number: JG2020098.

\section{References}

[1] Yang Anjie. Reflections on the construction of the security system of the applied university engineering training center. Henan Institute of Engineering Journal 2020 (12): 85-86.

[2] Xu Yudong, Huo Ying, Chen Hongbo, Xu Xue. Research and Practice on the construction of engineering practice teaching system under the background of Applied Undergraduate Education [J]. Journal of Jilin Institute of chemical technology, 2021,38 (02): 41-44 + 51.

[3] Jambi wins. Design and practice of engineering training management system platform for new engineering sciences. J. China Management Information 2021 (9): 217-218. Ma Kunlong. Short term distributed load forecasting method based on big data [D]. Changsha: Hunan University, 2014.

[4] Zhang Xu. Application of hybrid teaching in engineering training numerical control machine tool teaching J. Internal combustion engine and accessories 2009 (1): 242-243.

[5] Liu Chuncheng. Contradiction Analysis and Resolution Measures in Engineering Training Teaching. High School Journal 2021 (28): 82-83.

[6] Liu Liyuan. Research on engineering training teaching methods and teaching modes. Vocational Education and Training 2021 (2): 42-43. 